\title{
MANFAAT PENERAPAN MARKETING ONLINE (MENGGUNAKAN E-COMMERCE DAN MEDIA SOSIAL) BAGI USAHA MIKRO, KECIL DAN MENENGAH (UMKM)
}

\author{
Mukhsin \\ Teknik Komputer, Fakultas Teknik, Universitas Wiralodra \\ mukhsin_qrpratama@yahoo.com, mukhsin.ft@unwir.ac.id
}

\begin{abstract}
ABSTRAK
Perkembangan teknologi tidak hanya mengubah cara berkomunikasi masyarakat namun juga metode perdagangannya. Pertumbuhan e-commerce yang semakin banyak berguna menjadi tempat jual-beli barang secara online yang bisa digunakan oleh pengusaha. Kesempatan ini tidak dilewatkan oleh para pelaku usaha mikro, kecil dan menengah (UMKM), dimana marketplace untuk UMKM dimanfaatkan oleh pemilik usaha kecil menengah. Selama ini kendala yang selalu dihadapi oleh UMKM adalah masalah pemasaran, apalagi untuk UMKM di daerah. Media Sosial masih sebagai aktifitas pribadi, itu yang masih terlihat di pelaku UMKM, belum terjadi adanya kesungguhan Media Sosial menjadi bagian aktifitas strategis yang mewakili usaha. UMKM menjadi bagian dari perhatian karena kemampuan memahami bidang IT memang masih sangat beragam, sehingga kepedulian terhadap UMKM dimulai dari lingkungan sekitar dengan memacu partisipasi UMKM menggunakan media yang terjangkau menurut daya konsumsi UKM. Dengan adanya e-commerce merupakan peluang bagi UMKM, karena dengan menggunakan marketplace memungkinkan pasar UMKM akan lebih luas dan promosi lebih murah. Dari sisi promosi keuntungan berjualan di marketplace untuk UMKM melalui online adalah bisa menjaring lebih banyak pelanggan yang lebih luas. Semua orang yang terhubung dengan internet bisa melihat promosi tanpa terbatasi oleh geografis.
\end{abstract}

Kata Kunci: $\quad$ e-commerce, marketplace, media sosial, usaha mikro kecil dan menengah (UMKM)

\begin{abstract}
Technological developments have not only changed the way people communicate but also the methods of trading. The growing use of e-commerce is becoming a place for buying and selling goods online that can be used by entrepreneurs. This opportunity is not overlooked by micro, small and medium enterprises (MSMEs), where the marketplace for MSMEs is utilized by small and medium business owners. So far, the obstacles that have always been faced by MSMEs are marketing problems, especially for MSMEs in the regions. Social Media is still a private activity, that is still visible in MSME actors, there has not been any seriousness in Social Media being a part of strategic activities that represent business. MSMEs are part of the attention because the ability to understand the IT field is still very diverse, so that concern for MSMEs starts from the surrounding environment by spurring the participation of MSMEs using affordable media according to the power of SME consumption. With the existence of e-commerce is an opportunity for MSMEs, because using the marketplace allows the MSME market to be broader and promotions cheaper. In terms of promotion the benefits of selling in the marketplace for MSMEs through online is to be able to attract more customers. Everyone connected to the internet can see promotions without being geographically limited.
\end{abstract}

Keywords: $\quad$ e-commerce, marketplace, social media, micro small and medium enterprises (MSMEs).

\section{PENDAHULUAN}

Di era globalisasi informasi bergerak sangat cepat dan menjadi pelaku bisnis untuk memenangkan persaingan. Perkembangan strategi pemasaran kini sangat pesat didukung dengan kemajuan teknologi informasi saat ini. Internet melalui $e$ - commerce dan media online membuka peluang bagi usaha mikro, kecil dan menengah (UMKM) untuk memasarkan dan menumbuhkan jaringan usaha di seluruh belahan dunia usaha. Untuk itu pelaku UMKM dituntut menjadi bagian dari komunitas global dengan pemanfaatan teknologi informasi melalui $e$ commerce dan media sosial, jika mereka tidak mengikuti perkembangan teknologi informasi akan tertinggal jauh dan kalah dalam persaingan.

E-commerce dan media online merupakan salah satu cara yang dapat dilakukan oleh pelaku UMKM untuk memasarkan produknya selain dapat memperluas akses pasar. UMKM harus 
melihat manfaat e-commerce dan media sosial untuk akses pasar secara mudah dan effisien seiring era globalisasi yang pasti akan dihadapi. Kondisi ini menuntut UMKM untuk memilih yang efektif dan mengenai sasaran. Pemasaran melalui e-commerce dan media sosial membuat pelaku bisnis UMKM dapat langsung berkomunikasi dengan pembelinya, sehingga mereka dapat memproleh keuntungan yang lebih besar.

E-commerce dan media sosial untuk pemasaran produk UMKM dapat memproleh manfaat serta keuntungan karena lebih murah dan effisien. Selain itu e-commerce dan media sosial juga memiliki akses tanpa batas, saat sebuah bisnis memiliki alamat di internet, apa yang ditampilkan dalam internet dapat diakses oleh pengunjung dari belahan dunia manapun selama didaerah tersebut memiliki akses internet. Semakin sering alamat tersebut dikunjungi, semakin besar pula potensi untuk memperoleh pendapatan.

Namun tidak dapat dipungkiri bahwa kemajuan teknologi informasi tidak selamaya berakibat positif, tetapi banyak pula hal negatif yang ditimbulkan contohnya adanya beberapa oknum yang memanfaatkan kelemahan dari pemasaran melalui e-commerce dan media sosial yaitu rentan terhadap penipuan. Banyaknya konsumen yang tertarik dengan produk yang ditawarkan pada e-commerce dan media sosial membuat mereka mencari produk yang sama tetapi dengan harga yang jauh lebih murah mengakibatkan para konsumen lupa akan kualitas dari produk ataupun perusahaan yang menawarkan produk tersebut.[2]

\section{A. Marketing Online}

Pemasaran (Marketing) adalah proses merencanakan dan melaksanakan konsep, penerapan harga, promosi, dan distribusi ide (hasil pemikiran), barang, dan jasa untuk menciptakan pertukaran yang dapat memuas-kan tujuan individu maupun organisasi.[5]

Maka karenanya proses marketing meliputi baik aspek mental maupun aspek fisik. Mental dalam arti bahwa para penjual harus mengetahui apa yang diinginkan para pembeli dan pembeli harus mengetahui apa yang dijual. Fisik dalam arti bahwa benda-benda harus dipindahkan ke tempat-tempat diamana mereka dibutuhkan pada waktu mereka dibutuhkan.[2]

E-Marketing is the marketing side of $E$ Commerce, it consists of company efforts to communicate abaout, promote and sell products and services over the internet. E-Marketing is the marketing side of E-Commerce, which is the work of a company to communicate something, promote, and sell goods and services over the internet. [5]

Perkembangan teknologi informasi khususnya internet sangat mempengaruhi dunia marketing, bahkan banyak yang beranggapan penggunaan internet untuk marketing adalah pilihan yang tepat pada saat ini. Tingginya pengguna internet berbanding lurus dengan pemanfaatannya di kehidupan sehari-hari khususnya bidang marketing, sehingga dikatakan bahwa marketing online mulai populer sejalan dengan makin pupulernya penggunaan internet.[3]

Dalam pemasaran online lewat dunia maya, ada orang yang menyebut Cyber Marketing sebagai internet marketing. Yang sering disingkat dengan e-marketing. Beberapa konsep cyber marketing mencakup perencanaan strategi, analisa situasi, analisa costumer, pengembangan pasar dan produk, positioning, dan konsepkonsep lain. Akan tetapi, banyak diantara prinsip, teknik, dan taktik cyber marketing ini yang memang berakar pada strategi pemasaran tradisional meskipun implementasinya berbeda. Dimensi baru yang telah menyatu ke dalam, khususnya lanskap bisnis internet ini ialah pemasaran pesan-pesan iklan melalui media promosi internet jenis calssified, promosi berbasis testimonial di situs web, pemasaran melalui situs pencari, serta pemasaran dan pembelian berbasis email marketing. [4]

\section{B. E-Commerce}

Electronic commerce (e-commerce) merupakan konsep yang bisa digambarkan sebagai proses jual beli barang pada internet atau proses jual beli atau pertukaran produk, jasa, dan informasi melalui jaringan informasi termasuk internet.[8]

Electronic Commerce (E-Commerce) secara umum merupakan kegiatan bisnis (perniagaan/perdagangan) atau jasa yang berhubungan erat dengan konsumen (Consumers), Manufaktur, Internet Service Provider (ISP) dan Pedagang Perantara (Intermediateries) dengan menggunakan media elektronik. Dalam hal ini media elektronik utama dengan menggunakan internet. [6]

Bryan A. Garner juga menyatakan bahwa "E-Commerce the practice of buying and selling 
goods and services trough online consumer services on the internet. The e, ashortened from electronic, has become a popular prefix for other terms associated with electronic transaction". Dapat dikatakan bahwa pengertian e-commerce yang dimaksud adalah pembelian dan penjualan barang dan jasa dengan menggunakan jasa komputer online di internet.[4]

E-commerce juga dapat diartikan sebagai suatu proses berbisnis dengan memakai teknologi elektronik yang menghubungkan antara perusahaan, konsumen dan masyarakat dalam bentuk transaksi elektronik dan pertukaran/penjualan barang, servis, dan informasi secara elektronik.[6]

E-commerce menggambarkan cakupan yang luas mengenai teknologi, proses, dan praktek yang dapat melakukan transaksi bisnis tanpa menggunakan kertas sebagai sarana mekanisme transaksi. Penggunaan transmisi data secara elektronik untuk membantu proses bisnis.[8]

\section{Media Sosial}

Social media is a term that covers not only New Media platforms but also implies the inclusion of systems like FriendFeed, Facebook, and others that are generally regarded as social networks. The idea is that various media platforms have social components and as a medium of public communication.[1]

Media sosial adalah perkembangan mutakhir dari teknologi - teknologi perkembangan web baru berbasis internet, yang memudahkan semua orang untuk dapat berkomunikasi, berpartisipasi, saling berbagi, dan membentuk sebuah jaringan secara online, sehingga dapat menyebarluaskan konten secara sendiri. Media jejaring sosial merupakan situs yang menjadi tempat orangorang berkomonukasi dengan teman-teman mereka, yang mereka kenal di dunia nyata dan dunia maya. Media sosial adalah paradigma media baru dalam konteks industri pemasaran.[14]

\section{Usaha Mikro, Kecil dan Menengah}

Usaha mikro, kecil, dan menengah atau biasa disingkat UMKM. Hal ini telah diatur didalam Undang-Undang Nomor. 9 tahun 1995 tentang Usaha Kecil. Ada juga Peraturan Pemerintah Nomor 44 Tahun 1997 tentang kemitraan yang menjadi pelaksanaan lebih lanjut.[12] Berikut adalah pengertian dari UKM yang terdapat didalam Undang-Undang Nomor 9 Pasal 1 Tahun 1995: [10] a. Usaha Kecil adalah kegiatan ekkonomi rakyat yaang berskala kecil dan memenuhi kriteria kekayaan bersih atau hasil penjuaalan tahunan serta kepemilikan sebagaimana diatur dalam Undang-Undang ini,

b. Usaha Menengah dan Usaha Besar adalah kegiatan ekonomi yang mempunyai kriteria kekayaan bersih atau hasil penjualan tahunan lebih besar daro kekayaan bersih dan hasil penjualan tahunan usaha kecil.

Adapun pengertian dari Usaha Mikro, Kecil, dan Menengah (UMKM) dalam Undang-Undang Nomor 20 Tahun 2008 sebagai berikut : [11]

1. Usaha Mikro adalah usaha produktif milik orang perorangan dan/atau badan usaha perorangan yang memenuhi kriteria Usaha Mikro sebagaimana diatur dalam UndangUndang ini.

2. Usaha Kecil adalah usaha ekonomi produktif yang berdiri sendiri, yang dilakukan oleh orang perorangan atau badan usaha yang bukan merupakan anak perusahaan atau bukan cabang perusahaan yang dimiliki, dikuasai, atau menjadi bagian baik langsung maupun tidak langsung dari usaha menengah atau usaha besar yang memenuhi kriteria Usaha Kecil sebagaimana dimaksud dalam Undang-Undang ini.

3. Usaha Menengah adalah usaha ekonomi produktif yang berdiri sendiri, yang dilakukan oleh orang perseorangan atau badan usaha yang bukan merupakan anak perusahaan atau cabang perusahaan yang dimiliki, dikuasai, atau menjadi bagian baik langsung maupun tidak langsung dengan Usaha Kecil atau usaha besar dengan jumlah kekayaan bersih atau hasil penjualan tahunan sebagaimana diatur dalam UndangUndang ini.

Sesuai dengan pengertian di atas bahwa ada perbedaan yang sangat jelas antara usaha mikro dengan kecil dan usaha kecil dengan menengah. Perbedaan yang besar itu dari segi asset ataupun omzet yang di dapatkan atau dihasilkan dari usaha yang dijalankan. 


\section{METODE PENELITIAN}

\section{A. Metode Penulisan Karya Ilmiah}

Penulisan karya ilmiah ini dimaksud agar penulis dapat mendeskriptifkan pemanfaatan ecommerce dan media sosial dalam strategi pemasaran usaha mikro, kecil dan menengah (UMKM). Dalam Penulisan karya ilmiah ini penulis menggunakan metode penulisan deskriptif. Metode deskriptif dapat kita diartikan sebagai cara atau proses pemecahan masalah yang diselidiki dengan menggambarkan atau menjabarkan keadaan subjek atau objek dalam penelitian yang dapat berupa orang, lembaga, masyarakat dan yang lainnya yang pada saat sekarang berdasarkan fakta-fakta yang ada dan benar apa adnya tanpa ada pengurangan dan penambahan.

\section{B. Sasaran Khalayak/Responden}

Dalam penulisan karya ilmiah ini penulis mencoba untuk menentukan sasaran responden yang tidak lain adalah para pelaku UMKM khususnya di Kab. Indramayu. Penentuan sasaran ini dikarenakan penulis ingin mengetahui implementasi e-commerce dan media sosial terhadap perkembangan, peningkatan pemasaran dan peningkatan produktivitas usaha kecil menengah.

\section{Teknik Pengumpulan Data}

Disini dalam teknik pengumpulan data, penulis memakai beberapa Teknik yaitu wawancara dan observasi lapangan. Wawancara yang dimaksud ialah mencoba mendapatkan informasi yang diperlukan kepada narasumber yang sudah dipilih terlebih dahulu. Dalam Teknik wawancara informasi yang didapatkan bisa dalam wanwancara langsung yaitu bertemu atau bertatap muka langsung dengan narasumber. Adapun wawancara yang dilakukan melalui media elektronik. Tujuan dari adanya wawancara ini tidak lain adalah mendapatkan data-data yang diperlukan dalam penulisan karya ilmiah ini tanpa melupakan fakta yang sebenarnya.

Observasi lapangan adalah Teknik pengumpulan data yang sangat popular saat ini. Hal ini dikarenakan dalam prosesnya penulis mendaapatkan banyak data secara langsung dan benar adanya. Dengan melakukan Teknik observasi ini diharapkan penulis dapat menyajikan / menjabarkan gambaran realistic kejadian untuk mencapai tujuan penulis.

\section{Analisis Data}

Teknik analisis data yang digunakan dalam penulisan karya ilmiah ini adalah statistik deskriptif dan analisis kualitatif yang dimana data yang telah dikumpulkan dijabarkan kedalam tulisan karya ilmiah serta ditampilkan dalam bentuk tabel dan grafik.

Dalam proses penulisan karya ilmiah ini penulis juga membaca beberapa buku mencoba untuk mangaitkan dengan beberapa teori yang dianggap berkaitan oleh penulis.

\section{HASIL DAN PEMBAHASAN}

Setelah melakukan pencarian data-data yang dibutuhkan serta menganilis data yang terkumpul penulis mendapatkan hasil untuk menulis hasil karya ini. Diharapkan hasil analisis yang dilakukan oleh penulis bisa menjabarkan dengan apa adanya sesuai dengan fakta yang ada di lapangan.

\section{A. Karakteristik UMKM}

Subyek dalam penelitian ini adalah pemilik atau pengelola UMKM dengan jenis usaha jasa, industri atau dagang. Bidang usaha subyek penelitian di antaranya jasa fotografi, event organizer dan travel agnet, dagang makanan/minuman, industri makanan, garment, dan kerajinan. Sebagian besar UKM yang diteliti telah berdiri antara 0-5 tahun dan 5-10 tahun.

Tabel 1. Karakteristik UKM

\begin{tabular}{|l|r|}
\hline \multicolumn{1}{|c|}{ Karakteristik } & \multicolumn{1}{c|}{$\mathbf{n ( \% )}$} \\
\hline Jenis Usaha & \\
\hline - Jasa & $6(40,0 \%)$ \\
\hline - Dagang & $4(26,6 \%)$ \\
\hline - Industri & $5(33,3 \%)$ \\
\hline Bidang Usaha & \\
\hline - Makanan & $5(33,3 \%)$ \\
\hline - Fotografi & $1(6,7 \%)$ \\
\hline - Event Organizer & $2(13,3 \%)$ \\
\hline - Garment & $1(6,7 \%)$ \\
\hline - Kerajinan & $3(20,0 \%)$ \\
\hline - Travel Agent & $3(20,0 \%)$ \\
\hline Lama Usaha telah berdiri & \\
\hline - 0-5 th & $4(26,6 \%)$ \\
\hline - 5-10 th & $6(40,0 \%)$ \\
\hline$\bullet>10$ th & $5(33,3 \%)$ \\
\hline
\end{tabular}




\section{B. Implementasi E-Commerce dan Media Sosial Pada UMKM}

Seluruh UMKM yang dijadikan obyek pada penelitian ini telah mengimple-mentasikan $e$ commerce dan media sosial sebagai media informasi dan komunikasi perusahaan. Sebagian besar UMKM memanfaatkan berbagai jenis $e$ commerce dan media sosial untuk memasarkan dan mengiklankan produk barang dagang dan jasa perusahaan. Hampir seluruh UMKM menggunakan e-commerce bukalapak.com, tokopedia.com dan media sosial Facebook, twitter dan instagram untuk menampilkan profil perusahaan dan galeri produk perusahaan. Sebagian besar perusahaan menggunakan BBM, WhatsApp, dan e-mail untuk media informasi/komunikasi perusahaan dan pemasaran produk dari perusaahan.

Disamping itu, sebagian UMKM juga menggunakan media Blog, Line, dan Youtube untuk menampilkan profil perusahaan dan sebagai media informasi (e-commerce) perusahaan. Hampir setengah dari UMKM yang di observasi mengalokasikan anggaran biaya operasional sebesar Rp.500.000-Rp.1.000.000 untuk mengelola e-commerce dan media sosial sebagai media informasi/komunikasi dan pemasaran perusahaan. Dan sebagian besar UMKM memperbaharui informasi di media sosial setiap hari.

Tabel 2. Implementasi Penggunaan ECommerce dan Media Sosial di UMKM UKM.

\begin{tabular}{|l|r|r|}
\hline \multicolumn{1}{|c|}{ Variabel } & \multicolumn{1}{|c|}{ N } & \multicolumn{1}{c|}{$\%$} \\
\hline Jenis E-Commerce & & \\
\hline • Website/Blog & 5 & $33,3 \%$ \\
\hline - Bukalapak.com & 13 & $86,6 \%$ \\
\hline - Tokopedia.com & 10 & $66,6 \%$ \\
\hline Jenis Media Sosial & & \\
\hline - Facebook & 15 & $100,0 \%$ \\
\hline - Twitter & 10 & $66,6 \%$ \\
\hline - Instagram & 12 & $80,0 \%$ \\
\hline $\begin{array}{l}\text { - Black Berry Messager } \\
\text { (BBM) }\end{array}$ & 6 & $40,0 \%$ \\
\hline - WhatsApp (WA) & 15 & $100,0 \%$ \\
\hline - Line & 5 & $33,3 \%$ \\
\hline - Youtube & 7 & $46,6 \%$ \\
\hline - E-mail & 12 & $80,0 \%$ \\
\hline Biaya Operasional/Bulan & & \\
\hline - Rp. 100.000-200.000 & 5 & $33,3 \%$ \\
\hline - Rp. 201.000-500.000 & 4 & $26,6 \%$ \\
\hline
\end{tabular}

\begin{tabular}{|l|r|r|}
\hline \multicolumn{1}{|c|}{ Variabel } & \multicolumn{1}{c|}{ N } & \multicolumn{1}{c|}{$\%$} \\
\hline - Rp. 501.000-1.000.000 & 6 & $40,0 \%$ \\
\hline Frekuensi Update & & \\
\hline • Harian & 12 & $80,0 \%$ \\
\hline - Mingguan & 2 & $13,3 \%$ \\
\hline - Bulanan & 1 & $6,6 \%$ \\
\hline
\end{tabular}

Dari hasil penelitian yang dilakukan peneliti menunjukkan e-commerce bukalapak dan tokopedia lebih dikenal oleh kalangan pelaku UMKM dibanding dengan beberapa e-commerce lain yang ada di Indonesia. Media sosial Facebook, twitter, dan intagram, cenderung lebih disukai karena kemudahannya dalam membagikan informasi dan menarik perhatian dari target pasar.

Facebook dengan fungsi like dan kemudahan fitur share untuk berbagi informasi sesama pengguna facebook memberikan efek viral yang dapat meningkatkan performa pemasaran produk, ditambah dengan kemudahan berinteraksi dengan komentar sebelumnya memberikan efek domino untuk memperkuat image produk.

Twitter dengan fitur retweet, follower, dan subscriber dapat memudahkan membagikan informasi produk dan memberikan manfaat yang luar biasa dalam memasarkan produk.

Instagram dengan kemudahan memposting tampilan visual berupa still image dan short video, akan menjadikan produk yang paling sering di upload akan memiliki kecenderungan lebih tinggi menarik perhatian dari konsumen.

Jenis media sosial lain yang berpotensi dan juga dapat dimanfaatkan sebagai komunikasi pemasaran perusahaan namun belum digunakan oleh obyek penelitian ini diantaranya Google+, Linkedln, Pinterest, Tumblr, MySpace.

\section{Efektivitas Penerapan E-Commerce dalam Perkembangan UMKM \\ Electronic Commerce (E-Commerce)} merupakan salah satu jenis implementasi teknologi dalam hal meningkatkan persaingan bisnis dan penjualan produk produk dengan memasarkan berbagai macam produk atau jasa, baik dalam bentuk fisik maupun digital.

Dengan adanya layanan jasa berupa $E$ Commerce yang dapat secara cepat dapat dinikmati oleh pelanggan maupun pemilik produk dan jasa maka segala layanan yang diinginkan oleh para pelanggan dapat segera ditindak lanjuti dengan secepat mungkin, sehingga pemilik produk dan jasa tersebut akan 
mampu memberikan pelayanan yang terbaik dan tercepat bagi para pelanggan. Sebelumnya, pelanggan yang ingin membeli suatu produk diharuskan untuk mendatangi tempat dari penjual produk sendiri dan hal itu sangatlah tidak efisien bagi para pelanggan yang mempunyai kesibukankesibukan padat.

Dengan adanya layanan E-Commerce ini maka pelanggan dapat mengakses serta melakukan pesanan dari berbagai tempat. Dengan adanya era teknologi yang canggih saat ini para pelanggan yang ingin mengakses E-Commerce tidak harus berada di suatu tempat, hal itu dikarenakan di kota kota besar di Indonesia telah banyak tempat tempat yang menyediakan suatu fasilitas akses internet untuk memasuki situs $E$ Commerce.[13]

Disisi lain dengan segala kemudahan yang diberikan oleh E-Commerce tentunya juga akan memberikan efek bagi para pemilik produk dan jasa yang tak terkecuali adalah para pelaku Usaha Mikro Kecil dan Menengah. Namun kesiapan UMKM menggunakan E-Commerce sendirilah yang akan menentukan perkembangan UMKM tersebut.

Secara umum ada berbagai manfaat yang didapatkan ketika melakukan perdagangan dengan sistem e-commerce. Menurut Sholekan (2009) manfaat yang didapatkan adalah sebagai berikut: [6]

1. Keuntungan bagi perusahaan

- Memperpendek jarak. Perusahaan dapat lebih mendekatkan diri dengan konsumen.

- Perluasan Perluasan pasar. Jangkauan pemasaran menjadi luas dan tidak terbatas oleh area geografis.

- Perluasan jaringan mitra bisnis.

- Efisiensi.

2. Keuntungan bagi konsumen

- Efektif Konsumen bisa memperoleh informasi produk yang dibutuhkan dan bertransaksi dengan cepat.

- Aman secara fisik. Hal ini dikarenakan konsumen tidak perlu datang langsung ke toko.

- Fleksibel. Konseumen dapat melakukan transaksi dimana saja.

3. Keuntungan bagi masyarakat umum

- Mengurangi polusi dan pencemaran lingkungan.

- Membuka peluang kerja baru.

- Meningkatkan sumber daya manusia.
D. Manfaat Jika UMKM Menggunakan $E$ commerce

1. Meningkatkan Jangkauan Konsumen Dengan menggunakan e-commerce pelaku UMKM tentu bisa lebih mengenalkan produk mereka ke pasar yang lebih luas, melalui internet dan social media batasan wilayah dan jarak bisa diatasi, apalagi dengan adanya jasa kurir seperti PT POS, Jne, Tiki dan sebagainya.

2. E-commerce Mampu Meningkatkan Pendapatan.

Dengan semakin dikenalnya produk dari sebuah UMKM maka secara otomatis konsumen juga semakin bertambah, dan hasilnya UMKM akan mampu berkembang hingga meningkatkan sumber lapangan pekerjaan baru.

3. Menyumbang Pendapatan Daerah Regional Bruto

Ketika UMKM mulai merambah pasar nasional dan global dengan memanfaatkan internet dan e-commerce, pemerintah sendiri berjanji untuk membantu membuka kerjasama-kerjasama dengan negara-negara lain agar produk UMKM bisa diterima di negara tersebut. Selain itu perputaran uang yang mengalir antar daerah akan mengurangi kesenjangan sosial dan membentuk ekosistem perekonomian yang merata di seluruh Indonesia.[13]

\section{E. Pengaruh Implementasi Media Sosial terhadap Pengembangan UMKM}

Pengimplementasian media sosial pada UMKM memberikan manfaat di antaranya sebagai galeri produk, mendata kebutuhan supplier, mendata kebutuhan distributor, survey target konsumen, dan memantau konsumen. Di samping itu media sosial juga bermanfaat sebagai forum disukusi, membantu pengambilan keputusan, memberikan respon pada konsumen, mendata kebutuhan konsumen, sebagai media pemasaran dan iklan, dan sebagai saran kontak personal dengan konsumen.[7] 


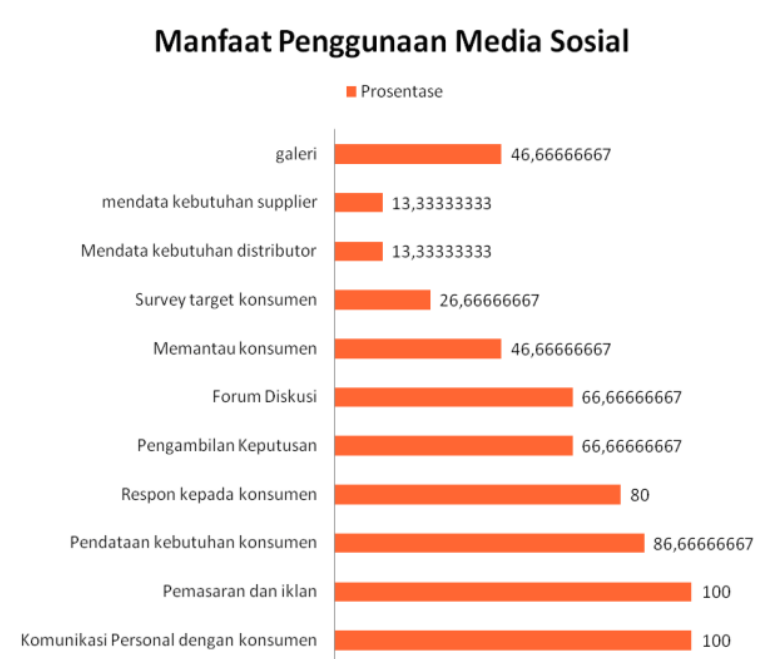

Gambar 1. Manfaat Penggunaan Media Sosial

Sosial media merupakan salah satu media yang mempermudah komunikasi interaktif antara pengusaha dengan siapapun, termasuk konsumen, dan berbagai pihak yang berkepentingan, kapanpun dan berada dimanapun. Sosial media sangat membantu sebagai penghubung informasi dan komunikasi dari produsen ke konsumen di manapun mereka berada dan berapapun jaraknya. Manfaat yang paling penting dari media sosial ini adalah tidak berbayar dan tidak memerlukan software khusus.[7]

\section{F. Manfaat Paling dirasakan Penerapan Marketing Online bagi UMKM}

Banyaknya manfaat penggunaan media sosial dalam mengembangkan UMKM merupakan salah satu faktor pendorong yang kuat bagi UMKM untuk terus memanfaatkan media sosial dalam rangka mengembangkan usahanya, meningkatkan penjualan produk, melakukan komunikasi dengan konsumen, serta mengembangkan jaringan pasar yang lebih luas lagi.[9]

Secara umum, pengelola UMKM dalam penelitian ini merasakan manfaat penerapan marketing online (penggunaan e-commerce dan media sosial) yang terbagi menjadi 7 jenis manfaat, meliputi: 1) Sebagai sarana iklan/promosi yang tercepat, praktis dan gratis, 2) Membantu brand awareness dan target audience, 3) Menambah pelanggan dan memperluas pangsa pasar, 4) Sebagai sarana pemasaran, 5) Mempermudah interaksi dan komunikasi dengan calon pembeli, 6) Meningkatkan penjualan secara signifikan, dan 7) Meningkatnya pengetahuan dalam membuat keputusan bisnis.

Tabel 3. Manfaat yang paling dirasakan Pengelola UMKM menerapkan marketing online.

\begin{tabular}{|c|c|}
\hline $\begin{array}{c}\text { Manfaat yang } \\
\text { paling dirasakan }\end{array}$ & $\begin{array}{c}\text { Pernyataan Pengelola } \\
\text { UMKM }\end{array}$ \\
\hline $\begin{array}{l}\text { 1. Sebagai sarana } \\
\text { iklan/promosi } \\
\text { yang tercepat, } \\
\text { praktis dan } \\
\text { gratis }\end{array}$ & $\begin{array}{l}\text { - Iklan/promosi tercepat } \\
\text { dan praktis } \\
\text { - Promosi secara cepat } \\
\text { dan tepat gratis } \\
\text { - Broadcast informasi }\end{array}$ \\
\hline $\begin{array}{l}\text { 2. Membantu } \\
\text { brand } \\
\text { awareness dan } \\
\text { target audience }\end{array}$ & $\begin{array}{l}\text { - Brand awareness dan } \\
\text { mencari target audience } \\
\text { lebih mudah }\end{array}$ \\
\hline $\begin{array}{l}\text { 3. Menambah } \\
\text { pelanggan dan } \\
\text { memperluas } \\
\text { pangsa pasar }\end{array}$ & $\begin{array}{l}\text { - Jadi banyak orang yang } \\
\text { tahu tentang promosi } \\
\text { dan akhirnya banyak } \\
\text { pembeli } \\
\text { - Memiliki banyak } \\
\text { pelanggan dari medsos } \\
\text { - Mendapatkan order dari } \\
\text { luar kota (Kab. } \\
\text { Indramayu) } \\
\text { - Promosi produk } \\
\text { menjadi lebih cepat } \\
\text { - Perusahaan lebih mudah } \\
\text { dan lebih cepat dikenal } \\
\text { pasar } \\
\text { - memperbanyak } \\
\text { konsumen, memperluas } \\
\text { pasar, (produk) lebih di } \\
\text { kenal } \\
\text { - Ada peningkatan dalam } \\
\text { pemasaran } \\
\text { - Orderan meningkat } \\
\text { - Peningkatan jumlah } \\
\text { konsumen dan omzet. }\end{array}$ \\
\hline $\begin{array}{l}\text { 4. Sebagai sarana } \\
\text { pemasaran }\end{array}$ & $\begin{array}{l}\text { - Sebagai sarana yang } \\
\text { baik dalam pemasaran } \\
\text { - Pemasaran jadi mudah }\end{array}$ \\
\hline $\begin{array}{l}\text { 5. Mempermudah } \\
\text { interaksi dan } \\
\text { komunikasi } \\
\text { dengan calon } \\
\text { pembeli }\end{array}$ & $\begin{array}{l}\text { - Mempermudah interaksi } \\
\text { dengan konsumen dan } \\
\text { calon pembeli } \\
\text { - Menghemat waktu dan } \\
\text { tenaga } \\
\text { - Mempermudah closing } \\
\text { (persetujuan transaksi) } \\
\text { - sarana efektif } \\
\text { berkomunikasi dan } \\
\text { Mempermudah interaksi } \\
\text { dengan pelanggan }\end{array}$ \\
\hline
\end{tabular}




\begin{tabular}{|c|c|}
\hline $\begin{array}{l}\text { Manfaat yang } \\
\text { paling dirasakan }\end{array}$ & $\begin{array}{c}\text { Pernyataan Pengelola } \\
\text { UMKM }\end{array}$ \\
\hline & $\begin{array}{l}\text { - (untuk) kontak dengan } \\
\text { pelanggan dan suplier" } \\
\text { - komunikasi lebih lancar } \\
\text { dan efisien } \\
\text { - mengetahui kebutuhan } \\
\text { dan keinginan } \\
\text { konsumen } \\
\text { - hubungan bisnis dengan } \\
\text { customer terjalin lebih } \\
\text { baik }\end{array}$ \\
\hline $\begin{array}{l}\text { 6. Meningkatkan } \\
\text { penjualan } \\
\text { secara } \\
\text { signifikan }\end{array}$ & $\begin{array}{l}\text { - Meningkatkan traffic } \\
\text { (penjualan) } \\
\text { - Mendongkrak penjualan } \\
\text { - Omset meningkat secara } \\
\text { signifikan }\end{array}$ \\
\hline $\begin{array}{l}\text { 7. Meningkatnya } \\
\text { pengetahuan } \\
\text { dalam } \\
\text { membuat } \\
\text { keputusan } \\
\text { bisnis }\end{array}$ & $\begin{array}{l}\text { - meningkatnya } \\
\text { pengetahuan dalam } \\
\text { membuat keputusan } \\
\text { bisnis } \\
\text { - mengetahui kompetitor } \\
\text { dan bisa mempelajari } \\
\text { apa yang harus } \\
\text { dilakukan selanjutnya } \\
\text { - jadi lebih update karena } \\
\text { mempelajari produk lain } \\
\text { melalui media social }\end{array}$ \\
\hline
\end{tabular}

\section{G. Penambahan Profit UMKM Setelah Menerapkan Marketing Online}

Penelitian ini menunjukkan bahwa penerapan marketing online (penggunaan $e$ commerce dan media sosial) pada UMKM membantu meningkatkan volume penjualan pada UMKM. Peningkatan penjualan paling banyak dirasakan UMKM sebesar 10-50\%. Hasil dari penelitian menjelaskan bahwa keuntungan yang diterima oleh UKM berkorelasi sangat kuat dengan adopsi dari Teknologi Informasi.

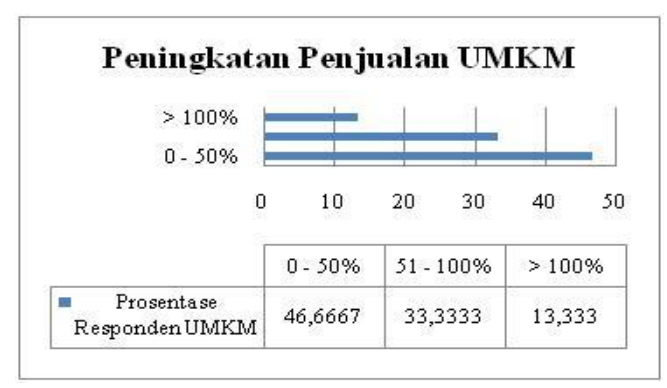

Gambar 2. Peningkatan penjualan produk UMKM setelah penerapan marketing online.
Penerapan marketing online (penggu-naan $e$ commerce dan media sosial) pada UMKM dapat meningkatkan jumlah penjualan UMKM hingga lebih dari $100 \%$, tapi sebagian besar peningkatan penjualan masih kurang dari $50 \%$. Berdasarkan hasil observasi terhadap UMKM dan marketing online yang digunakan, UMKM yang ber-hasil meningkatkan penjualan hingga lebih dari $100 \%$ karena Penerapan marketing online sebagai ujung tombak pemasaran dan komunikasi informasi UMKM, serta selalu melakukan update informasi produk dan perusahaan setiap hari. Sedangkan UMKM dengan peningkatan penjualan kurang dari $50 \%$, sebagian besar karena relatif jarang untuk melakukan update informasi dengan frekuensi update mingguan bahkan bulanan.

Keterbatasan penelitian ini adalah dilakukan secara cross sectional dan penilaian peningkatan penjualan berdasarkan wawancara dengan pemilik atau pengelola UMKM, sehingga tidak bisa diukur perubahan volume penjualan antara sebelum dan sesudah menerapkan marketing online.

\section{KESIMPULAN}

Penelitian ini menyimpulkan bahwa UMKM yang di observasi telah menerapkan marketing online (penggunaan e-commerce dan media sosial) dalam perusahaannya. E-Commerce yang paling dikenal adalah bukalapak dan tokopedia, Media sosial yang paling banyak digunakan adalah Facebook, Twitter dan Instagram.

Bagi sebagian besar UMKM manfaat penerapan marketing online adalah untuk komunikasi personal dengan konsumen, Pemasaran dan iklan, mendata kebutuhan konsumen, memberikan respon pada konsumen, membantu pengambilan keputusan dan sebagai forum diskusi dengan konsumen.

Berdasarkan penelitian penerapan marketing online dapat meningkatkan penjualan hingga lebih dari $100 \%$ apabila perusahaann melakukan update informasi secara konsisten melalui $e$ commerce ataupun media sosial setiap hari. Pengusaha UMKM perlu memanfaatkan $e$ commerce dan media sosial secara optimal dan secara konsisten melakukan update informasi setiap hari untuk mengembangkan pangsa pasar dan meningkatkan penjualan produk.

Penerapan marketing online memberikan efek bagi perkembangan pelaku UMKM mulai dari produktivitas hingga daya bertahan usaha. Meskipun dengan adanya peningkatan penjualan hingga produktivitas dari para pelaku UMKM, 
bantuan pemerintah terkait pemasaran melalui marketing online (E-Commerce dan media sosial) dinilai masih rendah yang ditunjukkan dengan hanya disediakannya layanan konsultasi dan pelatihan saja serta belum adanya paltform marketing online yang dibutuhkan pelaku UMKM untuk memasarkan produknya melalui sistem yang dibangun oleh Pemerintah Kabupaten Indramayu.

Perlu dilakukan penelitian lanjutan untuk melakukan pengukuran peningkatan penjualan secara akurat sehingga analisa pengaruh penerapan marketing online terhadap peningkatan penjualan bisa dilakukan lebih akurat.

Efektivitas Penerapan marketing online pada UMKM tentu masih membutuhkan berbagai macam perbaikan, hal ini juga dilakukan sebagai upaya untuk meningkatkan pembangunan perekonomian di wilayah Kab. Indramayu.

\section{DAFTAR PUSTAKA}

[1] A. O. Jagongo and C. Kinyua, The social media and entrepreneurship growth (a new business communication paradigm among SMEs in Nairobi), 2013.

[2] Andi Ashari, Pemanfaatan Media Sosial dalam Strategi Pemasaran Usaha Mikro Kecil dan Menengah (UMKM), Tema : Entrepreneur And Information Technolog, Jurnal, Fakultas Sosial dan Ilmu Politik ,Universitas Komputer Indonesia.

[3] Arif Ardiyanto, Analisis Penggunaan Media Sosial Dalam Pengembangan Usaha Mikro, Kecil, dan Menengah (UMKM) di Desa Kemasan Kecamatan Sawit Kabupaten Boyolali, Skripsi, Jurusan Manajemen Bisnis Syariah, Fakultas Ekonomi dan Bisnis Islam, Institut Agama Islam Negeri Surakarta, 2018.

[4] Karagozoglu, N, and M. Lindell, Electronic Commerce Strategy, Operations, and Performance inSmall and Medium Sized Enterprises, Journal of Small Business and Enterprise Development, 2004.

[5] Kotler, P., Keller, K.L., Marketing Management, Prentice Hall, New Jersey, 2012.
[6] Miftahus Sholihin, Siti Mujilahwati, Dampak Pemanfaatan E-Commerce Terhadap Peningkatan Penjualan di UMKM (Studi Kasus Ninda Bros Lamongan), Jurnal TeknikA, Vol 8 No 1, Program Studi Teknik Informatika, Fakultas Teknik, Universitas Islam Lamongan, 2016.

[7] Moch Hari Purwidiantoro, Dany Fajar Kristanto S.W., Widiyanto Hadi, Pengaruh Penggunaan Media Sosial terhadap Pengembangan Usaha Kecil Menengah (UKM), Jurnal EKA CIDA, Vol. 1 No. 1, AMIK Cipta Darma Surakarta, 2016

[8] Suyanto, M., Aplikasi IT untuk UKM Menghadapi Persaingan Global, Kedaulatan Rakyat, Yogyakarta, 2005.

[9] Swasta Priambada, Potensi Media Sosial Bagi Usaha Kecil Dan Menengah (UKM) di Malang Raya, Jurnal, Seminar Nasional Sistem Informasi Indonesia, Program Studi Administrasi Bisnis, Fakultas Ilmu Administrasi, Universitas Brawijaya, 2017

[10] Undang-Undang Nomor. 9 tahun 1995 tentang Usaha Kecil.

[11] Undang-Undang No 20 tahun 2008 Tentan Usaha Mikro Kecil dan Menengah.

[12] Peraturan Pemerintah Nomor 44 Tahun 1997 Tentang Kemitraan.

[13] Yuswan Tio Arisandi, Efektivitas Penerapan E-Commerce Dalam Perkembangan Usaha Kecil Menengah di Sentra Industri Sandal Dan Sepatu Wedoro Kabupaten Sidoarjo, Program Studi Ilmu Administrasi Negara, Departemen Administrasi, Fakulas Ilmu Sosial dan Ilmu Politik, Universitas Airlangga, 2017

[14] Zarrella, Dan, The Social Media Marketing Book, PT. Serambi Ilmu Semesta, Jakarta, 2010 
Halaman ini sengaja dikosongkan 